\title{
Pengembangan perangkat pembelajaran contextual guded inquiry untuk meningkatkan motivasi dan prestasi belajar matematika
}

\author{
Maria Noor Cahya Budhi \\ SMP IT Abu Bakar Yogyakarta. Jalan Veteran Gg. Bekisar No. 716 Q Pandeyan, Umbulharjo, \\ Yogyakarta 55161, Indonesia \\ Corresponding Author. E-mail: maria_widada@yahoo.co.id \\ Received: 1 April 2017; Revised: 17 September 2018; Accepted: 21 September 2018
}

\begin{abstract}
Abstrak
Penelitian ini bertujuan untuk menghasilkan perangkat pembelajaran matematika SMP dengan pendekatan contextual guided inquiry pada materi bangun ruang untuk meningkatkan motivasi dan prestasi belajar matematika siswa, yang valid, praktis dan efektif. Produk yang dikembangkan berupa RPP yang memuat langkah-langkah pendekatan contextual guided inquiry dan LKS yang memuat materi kontekstual dan langkah-langkah penemuan. Jenis penelitian ini adalah penelitian pengembangan yang mengadaptasi model pengembangan Dick \& Carey. Model pengembangan Dick \& Carey dimodifikasi sehingga menghasilkan 5 tahap pengembangan yaitu analisis kebutuhan dan perumusan tujuan; desain/pengembangan produk; uji coba produk; revisi produk serta produk akhir. Subjek dalam penelitian ini adalah 73 siswa kelas IX SMP IT Abu Bakar Yogyakarta. Instrumen yang digunakan dalam penelitian ini antara lain lembar validasi RPP dan LKS, lembar penilaian guru dan lembar tanggapan siswa, lembar observasi keterlaksanaan pembelajran, tes prestasi belajar serta angket motivasi siswa. Analisis data dilakukan dengan mengkonversi total skor aktual yang diperoleh menjadi data kualitatif skala lima. Dari hasil validasi ahli, skor penilaian guru, tanggapan siswa, observasi pembelajaran, angket motivasi dan tes prestasi belajar menunjukkan bahwa perangkat pembelajaran adalah valid, praktis, dan efektif. Dengan demikian, secara keseluruhan penelitian yang dilakukan menunjukkan bahwa produk yang dikembangkan layak untuk digunakan ditinjau dari aspek kevalidan, kepraktisan dan keefektifan.
\end{abstract}

Kata Kunci: pengembangan, perangkat pembelajaran, contextual guided inquiry

\section{Developing instructional kits by using the contextual guided inquiry approach to increase motivation and learning achievement of mathematics}

\begin{abstract}
This research aimed to produce mathematics instructional kits of junior high school by using contextual guided inquiry (CGI) on the topic of space building which is valid, practical and effective for increasing the motivation and mathematics learning achievement. The developed products are lesson plan which contained with the steps of CGI approach and worksheet which contaianed with the material developed and measures contextual discovery. This study was research and development addapted from Dick and Carey development methodology. The modified of this model resulted 5 stages of development steps, i.e. the needed analysis and the formulation of the goals; design/development of the product;test of the product; revision of the product as well as the final product. The subjects of this study are 73 grade 9 students of Abu Bakar Islamic private junior high school Yogyakarta. The instrument used in this research include validation sheet, teacher and students response sheets, observation sheet, achievement test and motivation quistionaire. The data analysis was done by converting the actual score into qualitative data with standard scale of five. Based on the results of validation experts, teacher's appraisal, students' response, learning observation, motivation questionnaires and achievement test the developed products are valid, practical and effective. In general, this study has shown that the developed products are reliable to be used as they fulfill the valid, practical and effectiveness aspects.
\end{abstract}

Keywords: development, instructional kits, contextual guided inquiry

How to Cite: Budhi, M. (2018). Pengembangan perangkat pembelajaran contextual guded inquiry untuk meningkatkan motivasi dan prestasi belajar matematika. Pythagoras: Jurnal Pendidikan Matematika, 13(1), 1020. doi:http://dx.doi.org/10.21831/pg.v13i1.13512 


\section{Pythagoras, 13 (1), 2018 - 11}

Maria Noor Cahya Budhi

\section{PENDAHULUAN}

Permendikbud No. 22 tahun 2016 tentang Standar Proses menyatakan bahwa proses pembelajaran pada satuan pendidikan diselenggarakan secara interaktif, inspiratif, menyenangkan, menantang, memotivasi peserta didik untuk berpartisipasi aktif, serta memberikan ruang yang cukup bagi prakarsa, kreativitas, dan kemandirian sesuai dengan bakat, minat, dan perkembangan fisik serta psikologis peserta didik. Oleh karena itu, setiap satuan pendidikan harus melakukan perencanaan, pelaksanaan serta penilaian kegiatan pembelajaran sehingga dapat tercipta suatu kegiatan pembelajaran yang efisien sehingga secara efektif meningkatkan ketercapaian kompetensi lulusan.

Idealnya, dalam kegiatan pembelajaran guru tidak hanya menggunakan satu jenis model pembelajaran saja. Perlu adanya variasi model pembelajaran yang digunakan, yang tentu saja harus disesuaikan dengan karakteristik siswa. Pengajaran yang dilandasi oleh pemahaman apa yang telah diketahui dan apa yang dibutuhkan peserta didik akan menciptakan pembelajaran yang efektif (NCTM, 2000, p.16). Untuk menciptakan kegiatan pembelajaran pembelajaran yang mampu memotivasi siswa untuk terlibat aktif, dibutuhkan strategi pembelajaran yang tepat. Begitu pula dalam pembelajaran matematika.

Pembelajaran matematika masih belum menjadi pembelajaran yang menyenangkan bagi semua siswa. Masih banyak siswa yang menganggap matematika sebagai mata pelajaran yang sulit. Ditambah lagi, matematika yang kini identik dengan soal-soal yang membutuhkan kemampuan berpikir tingkat tinggi, menjadi salah satu sumber kesulitan siswa. Hal ini sejalan dengan penelitian yang dilakukan oleh Hadi, Retnawati, Munadi, Apino, \& Wulandari (2018, p. 530) yang menemukan bahwa siswa banyak mengalami kesulitan dalam menyelesaikan soalsoal HOTS. Tentu saja, kesulitan-kesulitan ini dapat berpengaruh terhadap motivasi belajar matematika siswa.

Hasil wawancara yang telah dilakukan kepada 2 orang guru matematika di Yogyakarta menyatakan bahwa motivasi belajar matematika siswa terkategori masih rendah. Hal ini terlihat dari masih terdapat siswa yang mengantuk, mengobrol dengan teman sebangku, hingga membaca komik atau novel saat pembelajaran matematika sedang berlangsung. Selain itu, sebagian besar siswa terlihat tidak memperhatikan ketika guru sedang mengajar di depan kelas.
Berdasarkan asumsi tersebut, peneliti melakukan prasurvey untuk mengetahui motivasi belajar matematika siswa. Hasil prasurvey yang dilakukan pada 121 siswa menunjukkan bahwa masih terdapat sekitar $11 \%$ siswa yang mempunyai motivasi belajar rendah dan 3\% siswa yang mempunyai motivasi belajar yang sangat rendah. Hal ini mengindikasikan bahwa motivasi belajar matematika siswa masih perlu ditingkatkan.

Selain motivasi belajar, prestasi belajar matematika siswa juga dijadikan indikator keberhasilan suatu proses pembelajaran matematika di sekolah. Menurut pengalaman peneliti sebagai salah satu guru matematika di salah satu SMP swasta di Yogyakarta, berdasarkan hasil analisis dan ulangan harian siswa, peneliti menemukan bahwa siswa menemui beberapa kesulitan pada materi bangun ruang. Materi ini adalah bagian dari materi geometri yang berkaitan dengan bentuk, ukuran, posisi dan sifat ruang. Pada kompetensi dasar menyelesaikan masalah yang berkaitan dengan bangun ruang sisi lengkung, sebagian besar siswa mampu menyelesaikan soal terkait dengan penerapan rumus, tetapi mengalami kesulitan dalam menyelesaikan soal-soal yang membutuhkan kemampuan analisis. Hal senada terkait kesulitan siswa juga dikemukakan oleh Amri \& Abadi (2013, pp.58-59).

Mengacu pada Permendiknas No. 16 tahun 2007, seorang guru tentunya memiliki kompetensi pedagogik yang berkaitan dengan kemampuan membuat perencanaan pembelajaran yang sesuai dengan karakteristik siswa serta melakukan pengembangan kurikulum di tingkat satuan pendidikan yakni dengan menyusun silabus, RPP dan LKS. Jika dikaitkan dengan hal tersebut, guru tentu dapat merancang pembelajaran yang menyenangkan dan bermakna bagi siswa dengan memanfaatkan konteks sebagai media. Dengan melaksanakan pembelajaran yang menyenangkan dan bermakna, diharapkan masalah-masalah terkait motivasi dan prestasi belajar siswa dapat teratasi.

Dalam pelaksanaannya di kelas, diperlukan pemilihan pendekatan pembelajaran yang tepat. Menurut Burden \& Byrd (2013, p. 122) terdapat dua pendekatan dalam pembelajaran yaitu pendekatan yang berpusat pada guru (teacher centered) dan pendekatan yang berpusat pada siswa (student centered). Pendekatan yang berpusat pada guru (teacher centered) menurunkan strategi pembelajaran langsung (direct instruction), pembelajaran deduktif atau pembelajaran ekspositori. Pendekatan yang berpusat 


\section{Pythagoras, 13 (1), 2018 - 12}

Maria Noor Cahya Budhi

pada siswa (student centered) menurunkan strategi pembelajaran inkuiri dan pembelajaran induktif. Salah satu pendekatan pembelajaran yang berpusat pada siswa adalah CBL (Context Based Learning).

CBL (Context-Based Learning) adalah suatu pendekatan pembelajaran bermakna yang dalam penerapannya berpusat pada siswa dan menggunakan konteks sebagai skenario. Siswa dihadapkan pada masalah yang terbuka (openended), tidak terstruktur dan nyata (real-world) serta bekerja secara berkelompok untuk mengidentifikasi kebutuhan belajar siswa. Siswa kemudian mengembangkan solusi, didampingi oleh instruktur yang bertindak sebagai fasilitator dan bukan sebagai sumber utama dalam pembelajaran (Trimmer, Laracy \& Love-Gray, 2009; Gowri \& Missiriya, 2015; Tural, 2013; Arroio, 2010; Prince \& Felder, 2006).

Dalam pelaksanaan pembelajaran menggunakan CBL, masalah yang diberikan kepada siswa adalah masalah sehari-hari yang sering dihadapi oleh siswa. Masalah tersebut harus ditemukan penyelesaiannya dengan cara berdiskusi secara kelompok agar dapat memunculkan pengetahuan-pengetahuan baru yang dapat memperkokoh pengetahuan yang dimiliki oleh siswa. Hal ini sesuai dengan inti dari pembelajaran kontekstual yakni mengaitkan, mengalami, menerapkan, bekerja sama dan menerapkan (Satriani, Emilia \& Gunawan, 2012).

Salah satu pendekatan pembelajaran lain yang juga berpusat kepada siswa adalah Guided Inquiry. Guided Inquiry adalah pendekatan pembelajaran konstruktivis yang berdasarkan pada proses pencarian informasi untuk mengembangkan kompetensi dan meningkatkan pemahaman siswa terhadap materi pelajaran, menggunakan pertanyaan-pertanyaan sebagai panduan dalam penyelidikan (Kuhlthau, Maniotes \& Caspari, 2007; Nworgu \& Otum, 2013; Gerald, 2011; Obomanu, Nwanekzie \& Dorathy, 2014). Penelitian yang telah dilakukan oleh Ginanjar (2015, pp. 123-129) menemukan bahwa pembelajaran menggunakan metode inquiry ini dapat meningkatkan motivasi belajar siswa.

Penelitian ini akan menggabungkan antara CBL dengan guided inquiry. CBL memiliki ciri utama yaitu menggunakan masalah kontekstual sebagai materi pembelajarannya, sedangkan guided inquiry memiliki ciri utama yaitu adanya proses penemuan yang terbimbing. Adapun gambaran perpaduan antara CBL dan guided inquiry atau yang disebut dengan pendekatan Contextual Guided Inquiry (CGI) dalam penelitian ini adalah pendekatan pembelajaran yang dalam pelaksanaannya menggunakan materi atau masalah dalam kehidupan nyata atau memunculkan model, selanjutnya dilanjutkan dengan langkah-langkah penemuan terbimbing untuk menyelesaikan masalah tersebut. Berikut adalah sintaks pembelajaran dengan pendekatan $C G I$.

Tabel 1. Sintaks CGI dan Kegiatan Guru

\begin{tabular}{|c|c|}
\hline Tahapan & Kegiatan guru \\
\hline $\begin{array}{l}\text { 1. Orientasi } \\
\text { masalah }\end{array}$ & $\begin{array}{l}\text { Guru membantu siswa } \\
\text { mendefinisikan dan menyusun } \\
\text { tugas-tugas belajar yang terkait } \\
\text { dengan permasalahan }\end{array}$ \\
\hline $\begin{array}{l}\text { 2. Menyiapkan } \\
\text { bahan/referensi }\end{array}$ & $\begin{array}{l}\text { Guru mengarahkan siswa untuk } \\
\text { mengumpulkan informasi yang } \\
\text { diperlukan. }\end{array}$ \\
\hline $\begin{array}{l}\text { 3. Diskusi } \\
\text { pengarahan }\end{array}$ & $\begin{array}{l}\text { Guru mengarahkan siswa untuk } \\
\text { mengadakan eksperimen, dan } \\
\text { mencari penjelasan dan solusi. }\end{array}$ \\
\hline $\begin{array}{l}\text { 4. Kegiatan } \\
\text { penemuan }\end{array}$ & $\begin{array}{l}\text { Guru memfasilitasi siswa pada } \\
\text { kegiatan penemuan dengan } \\
\text { menggunakan bantuan LKS. }\end{array}$ \\
\hline $\begin{array}{l}\text { 5. Presentasi hasil } \\
\text { penemuan }\end{array}$ & $\begin{array}{l}\text { Guru memfasilitasi siswa } \\
\text { merencanakan dan } \\
\text { mempersiapkan presentasi. }\end{array}$ \\
\hline $\begin{array}{l}\text { 6. Pengembangan } \\
\text { dan tindak } \\
\text { lanjut }\end{array}$ & $\begin{array}{l}\text { Guru memfasilitasi siswa untuk } \\
\text { merefleksikan penyelidikan } \\
\text { mereka dan proses yang mereka } \\
\text { gunakan. }\end{array}$ \\
\hline
\end{tabular}

Dalam pembelajaran CGI, siswa dituntut untuk bekerja menyelesaikan masalah dengan melakukan penyelidikan dari berbagai sumber untuk menemukan konsep. Dengan adanya penguasaan konsep yang baik maka pembelajaran akan menjadi lebih bermakna. Perlu ditekankan bahwa dalam pelaksanaan CGI, siswa tidak hanya dituntut untuk menyelesaikan masalah dengan benar, tetapi diharapkan siswa mampu memahami masalah yang diberikan, memutuskan informasi manakah yang penting dari permasalahan yang dapat dijadikan petunjuk untuk menyelesaikannya, dan kemampuan apa yang harus mereka miliki untuk dapat menyelesaikan masalah secara efektif.

Merencanakan suatu kegiatan pembelajaran pada dasarnya bertujuan untuk menciptakan kondisi pembelajaran yang memfasilitasi siswa belajar secara aktif dan menyenangkan. Hal ini bertujuan agar siswa dapat meraih prestasi yang maksimal. Berdasarkan hal tersebut, maka penelitian ini bertujuan untuk menghasilkan perangkat pembelajaran matematika SMP dengan pendekatan Contextual Guided Inquiry (CGI) yang dapat meningkatkan motivasi dan prestasi belajar siswa. Produk yang dihasilkan dalam 
penelitian ini berupa Rencana Pelaksanaan Pembelajaran (RPP) dan Lembar Kerja Siswa (LKS).

\section{METODE}

Jenis penelitian ini adalah penelitian pengembangan dengan mengadaptasi model pengembangan Dick \& Carey (2001, pp.6-8) yang terdiri dari 10 langkah, yaitu identify instructional goals, conduct instructional analysis, analyze learners and contexts, write performance objectives, develop assessment instruments, develop instructional strategy, develop and select instructional material, design and conduct formative evaluation of instruction, revise instruction, dan design and conduct summative evaluation. Untuk kepentingan penelitian ini, dilakukan modifikasi langkah-langkah tersebut sesuai dengan kondisi lapangan sehingga diperoleh lima langkah pengembangan, yaitu analisis kebutuhan dan perumusan tujuan, desain/ pengembangan produk, uji coba produk, revisi produk serta produk akhir. Rincian modifikasi model pengembangan Dick \& Carey dapat dilihat pada Tabel 2.

Tabel 2. Modifikasi Model Pengembangan Dick \& Carey

\begin{tabular}{|c|c|c|}
\hline No. & Model Awal & Modifikasi \\
\hline 1. & $\begin{array}{l}\text { Identify instructional } \\
\text { goals }\end{array}$ & \\
\hline 2. & $\begin{array}{l}\text { Conduct instructional } \\
\text { analysis }\end{array}$ & Analisis kebutuhan \\
\hline 3. & $\begin{array}{l}\text { Analyze learners and } \\
\text { contexts }\end{array}$ & dan perumusan tujuan \\
\hline 4. & $\begin{array}{l}\text { Write performance } \\
\text { objectives }\end{array}$ & \\
\hline 5. & $\begin{array}{l}\text { Develop assessment } \\
\text { instruments }\end{array}$ & \\
\hline 6. & $\begin{array}{l}\text { Develop instructional } \\
\text { strategy }\end{array}$ & $\begin{array}{l}\text { Desain/ pengembangan } \\
\text { produk }\end{array}$ \\
\hline 7. & $\begin{array}{l}\text { Develop and select } \\
\text { instructional material }\end{array}$ & \\
\hline 8. & $\begin{array}{l}\text { Design and conduct } \\
\text { formative evaluation } \\
\text { of instruction }\end{array}$ & Uji coba produk \\
\hline 9. & Revise instruction & Revisi produk \\
\hline 10. & $\begin{array}{l}\text { Design and conduct } \\
\text { summative evaluation }\end{array}$ & Produk akhir \\
\hline
\end{tabular}

Uji coba produk yang dikembangkan dilaksanakan di Sekolah Menengah Pertama Islam Terpadu (SMP IT) Abu Bakar Yogyakarta. Subjek uji coba pada tahap uji coba terbatas melibatkan 15 siswa dengan tingkat kemampuan tinggi, sedang dan rendah. Pada tahap uji coba lapangan dilaksanakan di kelas IX E dan IX G melibatkan 73 siswa, yaitu 40 siswa dari kelas IX E dan 33 siswa dari kelas IX G, serta 2 orang guru matematika kelas IX.

Prosedur

Prosedur dalam penelitian ini mengacu pada lima langkah penelitian, yaitu analisis kebutuhan dan perumusan tujuan, desain/ pengembangan produk, uji coba produk, revisi produk serta produk akhir. Pada tahap analisis kebutuhan dan perumusan tujuan, dilakukan kajian pustaka dan studi lapangan. Kajian pustaka dilakukan dengan mengumpulkan informasi yang akan menjadi bahan perencanaan pembelajaran yaitu informasi terkait mata pelajaran matematika materi bangun ruang pada Kurikulum 2013, model pembelajaran, dan karakteristik siswa. Studi lapangan dilakukan dengan mengidentifikasi masalah mendasar yang berkaitan dengan urgensi pengembangan model pembelajaran dan pengumpulan informasi terkait RPP yang sudah ada selama ini dan digunakan oleh guru.

Pada tahap desain/pengembangan produk, dilakukan 4 kegiatan yaitu pemilihan format pembelajaran, perancangan perangkat pembelajaran, pemilihan media, dan pembuatan instrumen penelitian. Desain produk pengembangan meliputi RPP dan LKS yang menggunakan model pembelajaran contextual guided inquiry (CGI). Joyce \& Weil (1996, pp. 84-85) mengemukakan bahwa sebuah model pembelajaran terdiri dari tahapan-tahapan pembelajaran (syntax), sistem sosial (social system), prinsip dari reaksi (principles of reaction) dan sistem pendukung (support system). Sistem pendukung adalah kondisi yang diperlukan agar model pembelajaran dapat digunakan secara efektif dan efisien. Dalam penelitian ini, RPP dan LKS yang dikembangkan berkedudukan sebagai sistem pendukung model pembelajaran CGI.

Nieveen (1999, p.126) mengatakan bahwa hasil produk pendidikan memainkan peranan yang penting dalam pendidikan. Hal ini berarti produk harus mempunyai kriteria yang baik. Nieveen (1999, pp.127-128) mengatakan bahwa kualitas produk pendesainan, pengembangan, dan pengevaluasian program harus memenuhi kriteria valid, praktis, dan efektif. Untuk memenuhi kriteria pembelajaran dan kualitas produk yang baik, penelitian ini mengacu pada kriteria kualitas produk menurut Nieveen tersebut.

Tahap uji coba produk perangkat pembelajaran yang telah disusun meliputi proses validasi oleh ahli pendidikan matematika. Draft produk dikonsultasikan dan direvisi sesuai 


\section{Pythagoras, 13 (1), 2018 - 14}

Maria Noor Cahya Budhi

dengan saran validator. Apabila draf produk telah dinyatakan valid dan layak, draf produk tersebut kemudian digunakan dalam uji coba. Jika draf produk dinyatakan tidak valid dan tidak layak, maka dilakukan revisi besar.

Hasil revisi besar yang telah dilakukan harus divalidasi kembali oleh ahli dan praktisi hingga produk hasil revisi dinyatakan valid dan layak. Draf produk ini disebut dengan Draf 2. Selanjutnya dilakukan uji coba pada kelompok terbatas untuk menguji kualitas produk pengembangan dalam skala kecil terkait keterbacaan produk pengembangan. Jika hasilnya telah menunjukkan kriteria yang telah ditentukan, maka Draf 2 siap di uji cobakan. Jika belum, maka dilakukan revisi produk dan selanjutnya dilakukan uji coba terbatas. Draft produk ini disebut dengan Draf 3.

Draf 3 kemudian diujicobakan pada skala yang lebih luas, yaitu uji coba lapangan. Uji coba lapangan dilakukan untuk menguji kualitas produk yang dikembangkan yaitu perangkat pembelajaran berupa RPP dan LKS di sekolah yang menjadi subjek penelitian. Hasil uji coba lapangan ini disebut dengan Draf 4. Jika hasil uji lapangan telah memenuhi kriteria kepraktisan dan keefektifan, maka produk ini adalah produk akhir. Jika belum, maka dilakukan revisi produk. Hasil revisi harus diujicobakan kembali hingga diperoleh produk yang valid, praktis dan efektif. Instrumen

Instrumen yang digunakan meliputi: instrumen validasi format untuk mengetahui kevalidan instrumen yang akan digunakan dalam penelitian serta instrumen penilaian kevalidan yang terdiri dari lembar validasi RPP, LKS, tes prestasi belajar, dan angket motivasi belajar matematika siswa. Instrumen penilaian kepraktisan terdiri dari lembar penilaian guru terhadap produk pengembangan, lembar tanggapan siswa, dan lembar observasi keterlaksanaan pembelajaran. Instumen penilaian keefektifan terdiri dari tes prestasi belajar, dan angket motivasi belajar matematika siswa.

\section{Teknik Analisis Data}

Analisis data penelitian dilakukan untuk membuktikan kevalidan, kepraktisan dan keefektifan perangkat pembelajaran. Penilaian kevalidan ditinjau berdasarkan pada kekuatan landasan teoritis, sedangkan kepraktisan dan keefektifan ditinjau berdasarkan hasil respon siswa dan guru terhadap produk yang dikembangkan. Adapun penjelasan dari masing-masing teknik analisis data yang diperoleh adalah sebagai berikut.
Pembuktian kevalidan dilakukan untuk mengetahui tingkat kevalidan perangkat pembelajaran pada materi bangun ruang. Langkahlangkah penilaian kevalidan produk hasil pengembangan yaitu (1) mengubah data yang berupa skor penilaian validator yang diperoleh melalui lembar validasi menjadi data interval. Dalam lembar validasi disediakan lima pilihan untuk memberikan penilaian tentang kualitas produk yaitu tidak baik (nilai 1), kurang baik (nilai 2), cukup baik (nilai 3), baik (nilai 4), dan sangat baik (nilai 5). (2) Menjumlahkan skor dari validator menjadi skor aktual kemudian dikonversi ke dalam lima kategori penilaian. Kategorisasi hasil penilaian mengacu pada Tabel 3 .

Tabel 3. Pedoman Konversi Skor Aktual

\begin{tabular}{|c|c|c|}
\hline Interval skor & Nilai & Kategori \\
\hline$(M+1.5 s)<X$ & $\mathrm{~A}$ & $\begin{array}{l}\text { Sangat } \\
\text { Baik }\end{array}$ \\
\hline$(M+0.5 s)<X \leq(M+1.5 s)$ & B & Baik \\
\hline$(M-0.5 s)<X \leq(M+0.5 s)$ & $\mathrm{C}$ & $\begin{array}{l}\text { Cukup } \\
\text { Baik }\end{array}$ \\
\hline$(M-1.5 s)<X \leq(M-0.5 s)$ & $\mathrm{D}$ & $\begin{array}{c}\text { Kurang } \\
\text { Baik }\end{array}$ \\
\hline$X \leq(M-1.5 s)$ & $\mathrm{E}$ & $\begin{array}{l}\text { Tidak } \\
\text { Baik }\end{array}$ \\
\hline
\end{tabular}

Produk yang dihasilkan dikatakan valid jika hasil penilaian dari ahli memperoleh kategori minimal baik (B) dan hasil kesimpulan umum dari penilaian validator menyatakan bahwa perangkat layak digunakan (LD) atau layak digunakan dengan revisi (LDR). Apabila hasil penilaian masuk dalam kategori LDR, maka dilakukan revisi sesuai dengan masukan validator.

Kepraktisan produk yang dihasilkan diperoleh dari penilaian guru terhadap produk, tanggapan siswa terhadap proses pembelajaran dan pemanfaatan LKS, serta observasi keterlaksanaan pembelajaran dengan model $C G I$ di kelas. Produk hasil pengembangan dikatakan praktis jika guru memberikan penilaian dengan kategori minimal baik (B), peserta didik memberikan penilaian terhadap proses pembelajaran dan pemanfaatan LKS dengan kategori minimal baik (B), dan persentase keterlaksanaan pembelajaran hasil penilaian observer minimal mencapai $80 \%$. Jika tingkat pencapaian di bawah $80 \%$ maka perlu dilakukan revisi berdasarkan hasil pengamatan dan diskusi dengan guru.

Keefektifan produk yang dihasilkan diperoleh dari hasil tes prestasi belajar siswa dan angket motivasi belajar siswa setelah melakukan pembelajaran menggunakan CGI. Produk yang 
dihasilkan dikatakan efektif apabila persentase hasil tes prestasi belajar siswa memenuhi kriteria ketuntasan belajar secara klasikal yaitu minimal $80 \%$ dan rerata skor motivasi belajar matematika siswa berada pada minimal pada kategori tinggi.

Sebelum digunakan untuk mengukur motivasi dan prestasi belajar siswa, dilakukan estimasi reliabilitas tes prestasi belajar dan angket motivasi belajar matematika siswa. Hal ini bertujuan untuk mengetahui daya pembeda, tingkat kesulitan, analisis distraktor dan estimasi reliabilitas kedua instrumen tes tersebut. Estimasi reliabilitas tes prestasi dan angket motivasi belajar matematika siswa diperoleh menggunakan rumus Cronbach Alpha sebagai berikut.

$\alpha=\left(\frac{k}{k-1}\right)\left(1-\frac{\sum S D_{1}^{2}}{S D_{2}^{2}}\right)$

Keterangan:

$\alpha=$ estimasi reliabilitas

$k$ = banyaknya item soal

$S D_{1}{ }^{2}=$ varians skor butir ke-i

$S D_{2}{ }^{2}=$ varians total skor tes

Instrumen tes dikatakan reliabel jika koefisien reliabilitasnya mencapai $0,70 \quad(\alpha \geq$ 0,70) (Reynolds,2009, p.108).

\section{HASIL DAN PEMBAHASAN}

\section{Hasil}

Penelitian ini mengacu pada lima langkah hasil modifikasi dari model penelitian pengembangan Dick \& Carey yang meliputi analisis kebutuhan dan perumusan tujuan, desain/ pengembangan produk, uji coba, revisi produk dan produk akhir. Adapun penjelasan dari setiap langkah tersebut dalam penelitian ini adalah sebagai berikut.

\section{Analisis Kebutuhan dan Perumusan Tujuan}

Pada tahap ini, telah dilakukan telaah terhadap kebutuhan untuk selanjutnya dilakukan perumusan tujuan terkait dengan penelitian ini. Hasil telaah terkait kondisi siswa di lapangan menunjukkan bahwa masih rendahnya motivasi dan prestasi belajar matematika siswa. Secara umum siswa SMP Islam Terpadu Abu Bakar Yogyakarta mempunyai kemampuan akademik dalam kategori tinggi di kabupaten kota Yogyakarta. Selama lima tahun terakhir, hasil Ujian Nasional siswa sekolah tersebut menduduki peringkat ke-6 dari seluruh SMP/MTs negeri dan swasta se-kabupaten dan kota Yogyakarta. Akan tetapi, berdasarkan informasi dari pihak sekolah, kemampuan akademik siswa yang menjadi subjek uji coba lapangan yaitu siswa di kelas IXG dan kelas IX-E SMP Islam Terpadu Abu Bakar Yogyakarta tahun pelajaran 2015-2016 secara akademik memiliki kemampuan yang beragam. Pada kedua kelas tersebut terdapat siswa yang memiliki kemampuan kategori atas, kategori menengah dan kategori bawah.

Berdasarkan hasil telaah terhadap struktur kurikulum diketahui bahwa materi bangun ruang terdapat di dalam materi kelas VIII semester 2 yaitu Bangun Ruang Sisi Datar dan kelas IX semester 1 yaitu Bangun Ruang Sisi Lengkung. Perangkat pembelajaran yang dikembangkan dalam penelitian ini berkaitan dengan kedua materi tersebut. Rincian materi disusun secara sistematis, penyusunan materi disesuaikan dengan urutan kompetensi inti dan kompetensi dasar. Urutan materi disajikan dari menemukan unsur-unsur dan sifat-sifat bangun ruang, menemukan dan menghitung luas permukaan bangun ruang serta menemukan dan menghitung volume bangun ruang Hasil telaah yang juga telah dilakukan teerkait perangkat pembelajaran matematika SMP yang digunakan oleh guru menunjukkan bahwa dalam menyusun RPP guru lebih sering mengadopsi produk MGMP atau mendownloadnya dari internet.

Telaah kurikulum SMP dilakukan dengan memperhatikan cakupan materi sesuai dengan kompetensi inti dan kompetensi dasar yang terdapat pada kurikulum 2013, khususnya pada Permendikbud No. 68 tahun 2013 tentang KI dan KD serta teori belajar yang sesuai. Berdasarkan hal tersebut diperoleh hasil bahwa pendekatan pembelajaran yang cocok dengan karakter siswa SMP dalam pembelajaran tentang bangun ruang sisi datar dan sisi lengkung yaitu pendekatan saintifik dan model pembelajaran CGI (Contextual Guided Inquiry). Pendekatan saintifik dipilih karena sesuai dengan karakter kurikulum 2013, sedangkan model pembelajaran CGI dipilih karena menggunakan masalah-masalah kontekstual dan melibatkan siswa secara aktif dalam kegiatan pembelajaran. Di akhir pembelajaran, diharapkan motivasi dan prestasi belajar matematika siswa dapat meningkat.

Pada umumnya usia siswa SMP/MTs adalah 12-15 tahun. Menurut teori Piaget, perkembangan kognitif siswa SMP merupakan tahap awal dari formal operation yang merupakan transisi dari cara berpikir konkrit menuju cara berpikir formal. Ciri tahap ini adalah terjadinya pemikiran logis yang belum sempurna. Di rentang usia ini karakteristik siswa telah mampu diajak berpikir abstrak namun belum sempurna. 


\section{Pythagoras, 13 (1), 2018 - 16}

Maria Noor Cahya Budhi

Sehingga untuk menanamkan konsep masih diperlukan demontrasi atau presentasi non verbal. Pengalaman juga tidak kalah penting dalam proses pembelajaran sehingga belajar adalah proses mengkonstruksi pengetahuan yang pernah dialami. Oleh karena itu LKS yang dikembangkan dalam penelitian ini menampilkan masalahmasalah sehari-hari yang tidak asing bagi siswa serta menggunakan pendekatan penyelidikan dengan harapan siswa mengalami proses menemukan suatu konsep/informasi.

Analisis tugas bertujuan untuk menentukan tugas yang akan disampaikan pada siswa. Melalui tugas tersebut diharapkan siswa kemampuan menyelesaikan masalah siswa pada materi bangun ruang. Selain itu, tugas disesuaikan dengan kebutuhan yakni untuk meningkatkan motivasi dan prestasi belajar siswa sehingga indikator peningkatan motivasi dan prestasi belajar matematika kemudian disusun dan diimplementasikan bersamaan dengan indikator ketercapaian $\mathrm{KI} / \mathrm{KD}$. Secara lebih rinci tugas yang diberikan kepada siswa antara lain materi tentang menemukan unsur-unsur dan sifat-sifat bangun ruang, menemukan rumus luas permukaan bangun ruang, menghitung luas permukaan bangun ruang, menemukan rumus volume bangun ruang, menghitung volume bangun ruang, menyelesaikan masalah yang berkaitan dengan luas permukaan bangun ruang, dan menyelesaikan masalah yang berkaitan dengan volume bangun ruang.

Spesifikasi tujuan pembelajaran menjadi dasar penyusunan rancangan perangkat pembelajaran dan penyusunan tes hasil belajar. Tujuan pembelajaran pada materi bangun ruang dibagi menjadi dua aspek yaitu aspek kognitif dan afektif. Adapun indikator ketercapaian $\mathrm{KI} / \mathrm{KD}$ dirumuskan sebagai berikut. Melalui diskusi kelompok dalam pembelajaran bangun ruang, diharapkan siswa terlibat aktif dalam kegiatan pembelajaran dan bertanggungjawab dalam menyampaikan pendapat, menjawab pertanyaan, memberi saran dan kritik serta siswa dapat menentukan unsur-unsur bangun ruang, jaring-jaring bangun ruang, menghitung luas permukaan bangun ruang, dan menghitung volume bangun ruang. Sedangkan untuk aspek afektif diharapkan setelah pembelajaran selesai adalah membangun sikap kerjsama, kerja keras, dan kepedulian terhadap lingkungan dan orang lain, dan mengembangkan rasa ingin tahu siswa.

\section{Desain dan Pengembangan Produk}

Dengan memperhatikan hasil analisis materi, analisis siswa, analisis tugas, spesifikasi tujuan pembelajaran, selanjutnya dapat ditentukan format kegiatan pembelajaran yang dikembangkan yaitu menggunakan pendekatan saintifik dan model pembelajaran contextual guided inquiry yang berorientasi pada peningkatan motivasi dan prestasi belajar matematika siswa. Dalam pelaksanaan pembelajaran, media pembelajaran utama yang dianggap tepat untuk peningkatan motivasi dan prestasi belajar matematika siswa adalah Lembar Kerja Siswa (LKS). Oleh karena itu, produk dari penelitian pengembangan perangkat pembelajaran CGI ini terdiri dari Rencana Pelaksanaan Pelajaran (RPP), dan Lembar Kerja Siswa (LKS).

\section{Uji Coba Produk}

Pada tahap uji coba produk, Rencana Pelaksanaan Pelajaran (RPP), dan Lembar Kerja Siswa (LKS) yang telah disusun kemudian divalidasi oleh ahli pendidikan matematika. Hasil validasi ahli berupa masukan dan saran yang disampaikan terkait tata tulis, materi pembelajaran, format perangkat, dan kebahasaan.

Berdasarkan hasil penilaian ahli terhadap produk hasil pengembangan, dapat ditunjukkan bahwa produk yang dihasilkan termasuk dalam kategori valid/baik. Adapun hasil penilaian terhadap produk pengembangan dapat dilihat pada Tabel 4.

Tabel 4. Hasil Analisis Data Penilaian Ahli

\begin{tabular}{ccc}
\hline \multirow{2}{*}{ Validator } & \multicolumn{2}{c}{ Hasil Penilaian } \\
\cline { 2 - 3 } & RPP & LKS \\
\hline 1 & 151 & 88 \\
2 & 144 & 84 \\
Rata-rata & 147,5 & 86 \\
\hline Kategori & Baik & Baik \\
\hline
\end{tabular}

Berdasarkan Tabel 4 dapat dilihat bahwa skor nyata untuk RPP berada pada rentang skor $129,2<x<159,6$. Hal ini berarti RPP masuk dalam kategori valid. Skor nyata untuk LKS berada pada rentang skor $74,8<x<92,4$ sehingga dapat disimpulkan bahwa LKS juga masuk dalam kategori valid.

Jika produk penelitian yang dikembangkan mempunyai kategori minimal baik, maka produk penelitian memenuhi kualitas valid. Tabel 4 menunjukkan bahwa hasil validasi RPP dan LKS memperoleh penilaian B dengan kategori valid, sehingga produk termasuk dalam kriteria Layak Digunakan dengan Revisi (LDR) yang berarti 


\section{Pythagoras, 13 (1), 2018 - 17}

Maria Noor Cahya Budhi

bahwa produk telah memenuhi syarat untuk digunakan.

LKS materi bangun ruang dengan model CGI yang telah divalidasi ahli, kemudian diujicobakan secara terbatas kepada 15 siswa. Siswa diminta untuk membaca dan memberikan komentar tentang LKS hasil pengembangan serta mengisi lembar panduan keterbacaan. Siswa memberikan catatan tentang petunjuk pengerjaan LKS yang kurang dipahami dan kalimat pada soal cerita yang dianggap kurang efektif.

Selanjutnya, perangkat pembelajaran yang telah direvisi diujicobakan kepada 73 siswa kelas IX-G 33 siswa dan kelas IX-E 40 siswa SMP Islam Terpadu Abu Bakar Yogyakarta. Uji coba lapangan ini menghasilkan data yang dianalisis untuk mengetahui kepraktisan dan keefektifan perangkat pembelajaraan yang telah dikembangkan. Kepraktisan dapat diketahui dari lembar penilaian guru dan penilaian siswa serta lembar observasi keterlaksanaan pembelajaran, sedangkan keefektifan dapat dilihat dari hasil tes prestasi dan motivasi belajar siswa siswa.

Tabel 5. Hasil Analisis Data Penilaian Guru

\begin{tabular}{ccc}
\hline \multirow{2}{*}{ Guru } & \multicolumn{2}{c}{ Hasil Penilaian } \\
\cline { 2 - 3 } & RPP & LKS \\
\hline 1 & 35 & 32 \\
2 & 26 & 28 \\
Rata-Rata & 31,5 & 30 \\
\hline Kategori & Baik & Baik \\
\hline
\end{tabular}

Tabel 5 menunjukkan bahwa hasil penilaian guru terhadap produk hasil pengembangan berupa RPP dan LKS masuk dalam kategori praktis (B). Berdasarkan hal teersebut, dapat disimpulkan bahwa produk hasil pengembangan layak untuk digunakan. Hasil penilaian kepraktisan produk hasil pengembangan oleh 73 orang siswa mendapatkan skor 40,45. Berdasarkan pengkategorian yang telah dilakukan, skor nyata ini termasuk dalam kategori praktis. Dengan demikian LKS yang telah dikembangkan praktis untuk digunakan.

Tabel 6. Keterlaksanaan Pembelajaran

\begin{tabular}{ccc}
\hline Pertemuan ke & Skor & Persentase \\
\hline 1 & 20 & $100 \%$ \\
2 & 19 & $95 \%$ \\
3 & 18 & $90 \%$ \\
4 & 17 & $85 \%$ \\
5 & 18 & $90 \%$ \\
6 & 17 & $85 \%$ \\
7 & 19 & $95 \%$ \\
\hline
\end{tabular}

Analisis data yang diperoleh dari observasi keterlaksanaan pembelajaran pada setiap perte- muan dilakukan untuk menilai kepraktisan. Observer dalam penelitian ini adalah guru mitra. Adapun persentase keterlaksanaan pembelajaran dapat dilihat pada Tabel 6. Berdasarkan hasil penilaian guru, penilaian siswa dan data hasil observasi keterlaksanaan pembelajaran dengan pendekatan Contextual Guided Inquiry (CGI) maka perangkat pembelajaran dinyatakan memenuhi kriteria praktis.

Analisis keefektifan produk hasil pengembangan dilakukan berdasarkan data hasil tes prestasi dan angket motivasi belajar matematika siswa. Data hasil tes prestasi belajar diperoleh dari 73 siswa yang berasal dari kelas IX-E dan IX-G. Adapun data hasil tes prestasi belajar siswa disajikan pada Tabel 7.

Tabel 7. Hasil Analisis Data Prestasi Belajar

\begin{tabular}{ccccc}
\hline Kelas & $\begin{array}{c}\text { Jumlah } \\
\text { Siswa }\end{array}$ & Tuntas & $\begin{array}{c}\text { Belum } \\
\text { Tuntas }\end{array}$ & $\begin{array}{c}\text { Nilai } \\
\text { Rerata }\end{array}$ \\
\hline IX-G & 33 & 32 & 1 & 94,39 \\
IX-E & 40 & 38 & 2 & 90,50 \\
\hline Total & 73 & 70 & 4 & 92,45 \\
\hline
\end{tabular}

Hasil analisis data yang disajikan pada Tabel 7 menunjukkan bahwa ketuntasan klasikal mencapai $96 \%$, melebihi batas minimal ketuntasan klasikal yang ditentukan yakni $80 \%$. Selain itu, nilai rata-rata klasikal mencapai 92,45 yang berarti melebihi KKM yaitu 75 . Berdasarkan perolehan tersebut, dapat disimpulkan bahwa perangkat pembelajaran berbasis contextual guided inquiry yang dikembangkan mencapai kategori efektif ditinjau dari prestasi belajar.

Hasil analis data prestasi belajar siswa juga memberikan hasil bahwa kemampuan siswa dalam mengerjakan soal-soal pemecahan masalah bangun ruang sisi lengkung (soal nomor 4, 16, dan 17) sudah sangat baik. Hal tersebut dibuktikan dengan persentase siswa yang mampu menjawab benar sebanyak $96 \%$ (soal nomor 4), $85 \%$ (soal nomor 16 ), dan 95\% (soal nomor 17 ). Artinya, penguasaan materi dan kemampuan siswa dalam memecahkan masalah dapat terasah melalui pembelajaran menggunakan CGI. Hasil ini sesuai dengan hasil riset terdahulu yang dilakukan oleh Nworgu dan Otum (2013) yang juga menemukan bahwa metode contextual guided inquiry mampu meningkatkan pemahaman siswa terhadap materi pelajaran (Nworgu \& Otum, 2013).

Selain berdasarkan hasil tes prestasi belajar matematika siswa, keefektifan perangkat pembelajaran juga ditinjau dari hasil angket motivasi belajar siswa. Angket motivasi belajar matematika diberikan kepada 73 siswa yang 


\section{Pythagoras, 13 (1), 2018 - 18}

Maria Noor Cahya Budhi

berasal dari kelas IX-G dan kelas IX-E. Angket motivasi belajar diberikan setelah pelaksanaan pembelajaran menggunakan perangkat pembelajaran berbasis contextual guided inquiry hasil pengembangan, kemudian dianalisis secara ringkas dan diperoleh rata-rata 100,26 yang termasuk dalam kategori tinggi. Jadi dapat disimpulkan bahwa perangkat pembelajaran berbasis contextual guided inquiry yang dikembangkan mencapai kategori efektif ditinjau dari motivasi belajar.

Berdasarkan hasil analisis data angket motivasi belajar matematika siswa ditemukan beberapa catatan bahwa pada pada indikator hasrat dan keinginan berhasil, dorongan dan kebutuhan belajar yang merupakan indikator motivasi intrinsik, memperoleh kategori tinggi. Hal ini memperkuat dukungan terhadap teori yang menyatakan bahwa pembelajaran yang menggunakan pendekatan contextual guided inquiry mampu meningkatkan motivasi belajar siswa (Kuhlthau, Maniotes \& Caspari, 2007). Berdasarkan hasil tes prestasi dan angket motivasi belajar matematika siswa, dapat disimpulkan bahwa perangkat pembelajaran hasil pengembangan memenuhi kategori keefektifan.

\section{Revisi Produk}

Tahap keempat adalah revisi produk. Revisi perangkat pembelajaran bangun ruang dengan pendekatan contextual guided inquiry untuk meningkatkan motivasi dan prestasi belajar matematika dilakukan sebanyak tiga kali. Revisi pertama dilakukan setelah tahap validasi. Revisi kedua dilakukan setelah uji coba terbatas, dan revisi ketiga dilakukan setelah uji coba lapangan.

\section{Produk Akhir}

Tahap terakhir dalam penelitiann ini adalah kajian produk akhir. Menurut Nieveen (1999, p. 126), produk pengembangan yang berkualitas harus memenuhi kriteria kevalidan, kepraktisan dan keefektifan. Berdasarkan penilaian para ahli, produk akhir perangkat pembelajaran matematika SMP berbasis contextual guided inquiry pada materi pokok bangun ruang sisi datar dan bangun ruang sisi lengkung yang terdiri dari rencana pelaksanaan pembelajaran (RPP) dan lembar kegiatan siswa (LKS) yang telah dikembangkan telah memenuhi kriteria valid. Perangkat pembelajaran yang dikembangkan telah disusun dengan mengacu kepada metodologi pembelajaran yang berlandaskan pada konteks lingkungan sosial pembelajar dan konteks pengetahuan nyata (context-based learning) serta telah mengacu pada pendekatan pembelajaran konstruktivis yang berdasar pada proses pencarian informasi (guided inquiry).

Perangkat pembelajaran hasil pengembangan juga telah direvisi berdasarkan masukan dan saran dari ahli, guru mitra dan siswa sehingga diperoleh perangkat pembelajaran yang layak untuk digunakan.

Terkait dengan kepraktisan perangkat pembelajaran, berdasarkan uji lapangan yang telah dilakukan, diperoleh hasil penilaiaan dari guru mitra dan siswa terhadap perangkat pembelajaran yang telah dikembangkan. Hasil penilaian menunjukkan bahwa produk hasil pengembangan berupa RPP dan LKS telah mencapai kreteria praktis. Kreteria tersebut terpenuhi berdasarkan penilaian kepraktisan oleh guru yang menggunakan perangkat pembelajaran secara langsung yang memberikan penilaian dengan kategori praktis. Disamping itu, penilaian kepraktisan juga terpenuhi berdasarkan penilaian siswa yang mengikuti pembelajaran dikelas secara langsung yang memberikan penilaiann dengan kategori praktis. Kriteria kepraktisan yang terakhir dipenuhi berdasarkan tingkat keterlaksanaan kegiatan pembelajaran menggunakan perangkat yang telah dikembangkan yang menunjukkan kategori praktis. Dengan demikian secara keseluruhan kriteria kepraktisan perangkat pembelajaran yang dikembangkan telah terpenuhi.

Kriteria terakhir yakni keefektifan perangkat pembelajaran diperoleh berdasrkan hasil uji coba lapangan yang telah dilaksanakan. Secara umum, hasil uji coba menunjukkan bahwa perangkat pembelajaran hasil pengembangan telah memenuhi kategori efektif. Uji coba menunjukkan kriteria efektif ditinjau dari hasil tes prestasi belajar yang mencapai tingkat ketuntasan $96 \%$, yang artinya sekitar $96 \%$ dari keseluruhan siswa telah mencapai KKM. Demikian juga untuk kriteria keefektifan berdasarkan motivasi belajar siswa. Hail analisis menunjukkan bahwa rata-rata skor motivasi belajar siswa mencapai 100,26 termasuk kategori tinggi, sehingga kriteria keefektifan terpenuhi.

Berdasarkan kriteria kevalidan, kepraktisan, dan keefektifan, produk hasil pengembangan berupa perangkat pembelajaran telah terpenuhi,. Dengan demikian, diperoleh suatu produk akhir dari peneitian ini yaitu sebuah perangkat pembelajaran matematika SMP pada materi bangun ruang dengan pendekatan contextual guided inquiry yang valid, praktis, dan efektif sehingga layak digunakan untuk pembelajaran di sekolah. 


\section{Pythagoras, 13 (1), 2018 - 19}

Maria Noor Cahya Budhi

\section{SIMPULAN}

Berdasarkan uraian hasil pengembangan, dan analisis data uji coba, diperoleh kesimpulan bahwa hasil pengembangan perangkat pembelajaran matematika SMP materi bangun ruang menggunakan pendekatan pembelajaran contextual guided inquiry (CGI) untuk meningkatkan motivasi dan prestasi belajar matematika siswa yang terdiri dari Rencana Pelaksanaan Pembelajaran (RPP) dan Lembar Kerja Siswa (LKS) valid, praktis dan efektif. Pada tahap validasi ahli, produk hasil pengembangan dinyatakan valid. Berdasarkan uji coba lapangan, diperoleh hasil bahwa penilaiaan dari guru maupun siswa terhadap produk hasil pengembangan serta hasil observasi keterlaksanaan pembelajaran yang telah dilakukan telah memenuhi kriteria praktis. Penilaian keefektifan berdasarkan hasil tes prestasi dan angket motivasi belajar matematika siswa menunjukkan bahwa pembelajaran menggunakan perangkat pembelajaran hasil pengembangan telah memenuhi kriteria efektif.

Produk hasil pengembangan dapat dimanfaatkan untuk pembelajaran di kelas pada materi bangun ruang untuk meningkatkan motivasi dan prestasi belajar matematika siswa. Karena produk penelitian ini masih terbatas hanya pada materi bangun ruang, disarankan kepada peneliti lain agar dapat mengembangkannya pada materi-materi yang lain.

\section{DAFTAR PUSTAKA}

Amri, M., \& Abadi, A. (2013). Pengaruh PMR dengan TGT terhadap motivasi, sikap, dan kemampuan pemecahan masalah geometri kelas VII SMP. Pythagoras: Jurnal Pendidikan Matematika, 8(1), 55-68. doi:http://dx.doi.org/10.21831/pg.v8i1.84 94

Arroio, A. (2010). Context-based learning: A role for cinema in science education. Science Education International, 21(3), 131-143

Burden, P. R., \& Byrd, D. M. (2013). Methods for effective teaching. Washington DC: Pearson.

Dick, W., Carey, L., \& Carey, J. O. (2001). The systematic design of instruction, $6^{\text {th }}$ edition. Florida: Pearson

Gerald, L. F. (2011). The twin purposes of guided inquiry: Guiding student inquiry and evidence based practice. Scan's, 30(1), 2641.
Ginanjar, A. (2015). Pengaruh metode inkuiri terhadap motivasi belajar siswa SMP. Jurnal Riset Pendidikan Matematika, 45(2), 123-129. Retrieved from http://journal.uny.ac.id/index.php/jk/articl e/view/7489

Gowri, M \& Missiriya, M. A. S. (2015). Context based learning: Introducing newer learning approach in nursing. International Journal of Pharma and Bio Sciences, 6(4), 72-76.

Hadi, S., Retnawati, H., Munadi, S., Apino, E., \& Wulandari, N. F. (2018). The difficulties of high school students in solving higherorder thinking skills problems. Problems of Education in the 21st Century, 76(4), 520-532.

Joyce, B., \& Weil, M. (1996). Model of teaching $5^{\text {th }}$ edition . Boston, MA: Pearson Education, inc.

Kuhlthau, C. C., Maniotes, L. K., \& Caspari, A. K. (2007). Guided inquiry : Learning in the $21^{\text {st }}$ century school. New York, NY: Libraries Unlimited.

NCTM. (2000). Principles and standards for school mathematics. Reston, VA: The National Council of Teachers of Mathematics, Inc.

Nieveen, N. (1999). Prototyping to reach product quality. London: Kluwer Academic Publisher.

Nworgu, L. N., \& Otum, V. V. (2013). Effect of guided inquiry with analogy instructional strategy on students acquisition of science process skills. Journal of Education and Practice, 4(27), 35-41.

Obomanu, B. J., Nwanekzie, A. U., \& Dorathy, R. E. (2014). Relative effect of two forms of pedagogy on secondary school students performance in ecology concepts in rivers state. International Journal of Education and Research, 2(10), 237-250.

Prince, M. J \& Felder, R. M. (2006). Inductive teaching and learning methods: definition, comparisons and research bases. Journal Engr. Education, 95(2), 123-138.

Republik Indonesia. (2007). Peraturan Menteri Pendidikan Nasional Nomor 16, tentang standar kualifikasi akademik dan kompetensi guru.

Republik Indonesia. (2013). Peraturan Menteri Pendidikan dan Kebudayaan Nomor 68, 
Pythagoras, 13 (1), 2018 - 20

Maria Noor Cahya Budhi

tentang kompetensi inti dan kompetensi dasar matematika SMP/MTs.

Republik Indonesia. (2016). Peraturan Menteri Pendidikan dan Kebudayaan Nomor 22, tentang standar proses.

Reynolds, C. R. (2010). Measurement and assessment in education, second edition. New Jersey, NJ: Pearson.

Satriani, I., Emilia, E., \& Gunawan, M. H. (2012). Contextual teaching and learning approach to teaching writing. Indonesian
Journal of Applied Linguistics, 2(1), 1012.

Trimmer, W., Laracy, K., \& Love-Gray, M. (2009). Seeing the bigger through contextbased learning. Wellington, New Zealand: Good Practice Publication Grants, Ako Aotearoa National Centre for Tertiary Teaching Excellence.

Tural, G. (2013). The functioning of contextbased physics instruction in higher education. HKIEd APFSLT, 14(1), 1-23. 